\title{
A Study of the Impact of Saving on Macroeconomic Variables in Iran (CGE Model)
}

\author{
Nazar Dahmardeh \\ Associate Professor, University of Sistan and Baluchestan \\ Tel: 98-91-5141-9054Ｅ-mail: nazar@hamoon.usb.ac.ir \\ Mahdi Shahraki \\ Faculty member of Economics, Chabahar Maritime University (CMU) \\ Tel: 98-91-5342-5723 E-mail: shahraki@cmu.ac.ir \\ Simin Ghaderi \\ $\mathrm{PhD}$ student, Department of Economics, University of Sistan and Baluchestan \\ Tel: 98-545-412-2195Ｅ-mail: siminghaderi@yahoo.com
}

Received: September 13, 2011

doi:10.5539/ijef.v4n2p204
Accepted: October 14, $2011 \quad$ Published: February 1, 2012

URL: http://dx.doi.org/10.5539/ ijef.v4n2p204

\begin{abstract}
Economic fluctuations as well as endogenous and exogenous shocks lead to extensive changes in household saving indexes. Changes of household savings can also influence macroeconomic variables. Thus, in this study, the impact of household savings on Income and Gross Domestic Product in Iran in a Computable General Equilibrium (CGE) Model was investigated. The researchers used Static and Dynamic General Equilibrium Models by applying the Mixed Complementary Problems (MCP) method with two scenarios. In the Static Model, the investigation of households' income indicated that the income earned by urban and rural households through supplying capital and labor hit $0.31 \%$ and $0.5 \%$ respectively. The GDP in all economic sectors has also increased. Moreover, following the first scenario in the Dynamic Model, the rural and urban households' income increased by $6.42 \%$; however, it declined at the same rate as a result of implementing the second scenario, which is indicative of the fact that there is a positive relationship between households' income and their savings. The average GDP increased by $9.66 \%$ thanks to the implementation of the first scenario. In conclusion, it was found that opposite results were reached by implementing the second scenario.
\end{abstract}

Keywords: Saving, Income, Gross Domestic Product, Computable General Equilibrium (CGE) Models, GAMS

\section{Introduction}

The differences and distinctions among countries in their levels of development are related to their ability in investment, capital formation, and production; and supplying resources for investment is totally dependent upon the amount of the society's savings. In economy, the national savings typically consist of three basic elements: private savings, government's savings, and foreign savings. Private savings include households' savings, and private enterprises' savings, a great part of which is made up of households' savings. The government's savings simply mean the surplus of the government's revenues to government's expenditures, which, in Iran, is to a large extent dependent upon world oil markets and the revenues earned out of exporting oil. Having regards to changes in the world oil market as well as the general policies of Article 44 of the Islamic Republic of Iran's Constitution for strengthening the private sector, and in accordance with the objectives specified in the 20-year Plan for National Development, it seems that the main movement for equipping saving resources should address the private sector's savings. Thus, in this paper, the effect of household savings on the household income and Gross Domestic Product (GDP) will be studied in a Computable General Equilibrium (CGE) Model.

Computable General Equilibrium (CGE) Models consider the equilibrium for all the markets in the economy simultaneously. These models are widely used to assess and analyze the effects of the policies and shocks imposed on the economy. They enjoy the advantage of linking different production sectors, establishing links among different levels of microeconomics and macroeconomics, and using the basic principles of optimizing the behavioral pattern of microeconomics at macroeconomic levels. The theoretical basis of Computable General Equilibrium 
Model is the theory of Valeras, in which customers optimize their utility with regard to budget constraints, and the producers are also trying their best to gain the maximum benefit. In such a situation, the prices are adjusted endogenously to the point that the markets are cleared, and the result is that demand equals supply. Valeras models have originated from the study of Harberger's work (1962) on tax using a partially computable model. The work of Scarf (1973) made it possible to attain equilibrium in a Valeresian atmosphere. The prominent researches of Scarf \& Shoven (1984), Shoven \& Whalley (1992), Hertel's recent Global Trade Analysis Project (GTAP) (1997), and also Ginsburg \& Keyser's study (1997) strengthened this set of models more than ever.

Computable General Equilibrium Models have been applied as a useful and standard tool for experimental analysis in economy. In recent years, due to the improvements in specifying the models, supplying the required numerical data, and the increasing improvement of related computer software, the use of Computable General Equilibrium Models in developing countries has substantially increased. Using these models has not only reduced the cost of analyzing policies, but it has also produced results which are more compatible with the realities of the societies under study.

These models can be defined in both static and dynamic states. Static General Equilibrium Models are generally used for comparative studies, while Dynamic General Equilibrium Models are mostly used for studying the growth of the variables, and estimating the effect of one shock in future periods, and also for drawing and analyzing the timelines of the variables in question. These models include a series of simultaneous equations, some of which are linear, and some non-linear, and express the economic behavior of different sectors of the economy. What is important in Computable General Equilibrium Models is that besides the structural relations among different industrial units and organizations, the optimization conditions are also taken into consideration.

Aghveli and colleagues (1990), in International Monetary Fund, did a thorough study in 85 developing countries using the Panel data method. Their findings suggested that the rate of national net savings has a positive correlation with economic growth, and has a negative correlation with inflation rate, liquidity divided by national gross product, and urbanization rate. Gulalti and Thiman (1997) conducted a study in Latin America and Southeast Asia between 1975 and 1995, and investigated the effect of different factors on private savings using Panel Data method. They came to the conclusion that the government budget deficiency divided by gross domestic product, social welfare organization cost divided by gross domestic product, inflation has negative influence, but the savings of pension fund divided by gross domestic product, financial markets development, per capita income, production growth have positive influence on private savings. Cardenas and Escobar (1998) studied the determining factors of saving in Colombia between 1925 and 1994, using causality and cointegration tests. They confirmed the positive relationship between income and saving. Looney (2001) investigated the causal relationship between domestic savings and economics growth in Pakistan, and concluded that their relationship is mutual. Mary, Ramos, and Rios (2003) investigated the relationship between savings and economic growth using the Granjer causality test. The results obtained in this study are in accordance with the findings of the Solow model, which indicated that high rate of savings leads to high rate of economic growth. Other findings were that there was a direct relationship between general savings, family savings, or government savings, and income. Bout and colleagues (2006) did a research on family savings behavior in Pakistan between 1972 and 2003. They used the Johanson and Jo Silios economic analysis method, and Error Correction model. They studied the effect of per capita income, per capita income growth, population features such as the proportion of young population to the total population, or the proportion of old population to the total population, real interest rate, inflation rate on family savings. They found out that per capita income, per capita income growth, and real interest rate influence the family savings positively, however the inflation rate influences the family savings negatively. Mohan (2006) conducted a research in order to investigate the causal relationship between domestic savings and economic growth for economies with different levels of income in 13 countries between 1960 and 2001, using Granjer causality method. The findings suggest that in most of the countries with low levels of income, the economic growth rate influences the savings growth rate, but in countries with high levels of income, this relationship is mutual. Rahmani (1992) showed that rate of national savings has a positive correlation with per capita gross domestic production growth, and the proportion of employed population to the total population, but is negatively correlated with the added value of services sector divided by gross domestic product, and the rate of inflation. Karimi (1995) in his M.A. thesis came to the point that the amount of savings increases with the increase in permanent income, and that the rate of interest does not have any influence on national savings. Rashidi (1997) revealed that increase in disposable income, per capita income, payment balance, and real interest rate had positive impact on national income. Mojtahed and Karami (2004) came to the conclusion that the effect of economic growth and per capita income on the rate of savings is positive, and the effect of inflation rate on savings rate is negative. Bahrami and Aslani (2006) studied the effect of different factors on the private sector savings in Iran between 1970 and 2002, using the Autoregressive Distribute Lag. They confirmed the positive 
effect of increase in private sector disposable income, improvement in the income distribution, and ever-increasing development of financial markets on the private sector savings, and that increase in social welfare costs has a negative effect on private sector savings. Saadi (2006) studied the influential factors of Iran domestic savings. The statistics of years 1972- 2004 are used in this study. He studied the long-term relationship between the model factors using the co-integration test, and Granjer causality method. Growth of national domestic product, current account balance, population growth, and fluctuations in oil price have positive direct correlation with savings, and the correlation between inflation and savings rate is negative

\section{The Structure and Relations of the Model}

This paper, which aims to study the effect of household savings on its income and Gross Domestic Product (GNP), employs both Static General Equilibrium Model and Dynamic General Equilibrium Model, and finds the solution through Mixed Complementary problems (MCP). The Static General Equilibrium Model is used this model has 141 variables, 128 of which are endogenous variables, and 13 of which are exogenous. The static model is converted into a dynamic model by adding the equations related to the dynamic nature of the demand for labor force and capital formation (Thurlow, J. 2004). Due to its changing nature, the dynamic model includes 24 new variables besides the variables of the static model. This dynamic model is recursive, and has been devised for a 30-year period. Having been specified, the equations of this model have been changed into a computer programming language in a software package called General Algebraic Modeling System (GAMS). The statistics and data related to the variables and coefficients are mostly calibrated using Social Accounting Matrix prepared for Iran in 2004. In this model, household saving is considered as a Kinsey long-term saving function which equals the result of the household's marginal propensity for saving multiplied by the household's disposable income. In order to study the changes in the household's savings, we have used the changes of the household's marginal propensity for saving. As you see in Table 1, the model provided in this study consists of six categories: (1) Activities, (2) Goods, (3) Production Factors, (4) Households, (5) Investment-Saving and (6) other Institutions. The structure and relations of the model will be explained in the following sections.

\subsection{Prices}

One of the basic features of the Computable General Equilibrium(CGE) Model is that it deals with prices exactly and thoroughly. Figure 1 shows how producer's prices are changed into final goods prices. Since the production of goods entails many activities, we should first of all add all the prices for such activities (PXAC), and reach a single producing price, shown by PX. The final domestic market price of the product (PDS) is gained through the interaction between the export prices and producer's prices.

Given that Iran's market is small and price taker in comparison with the world market, we have considered world export prices (PWE) and world import prices (PWM) as exogenous in order to reach the domestic export and import prices. By adding import tariffs to world import prices, and changing it into the domestic currency, we reach the imported goods domestic price (Equation 1). And by subtracting the export tax from world export prices, and changing it into the domestic currency, we gain the exported goods domestic price (Equation 2). (See Appendix A)

By changing the focus of the discussion from supply to demand and consumption, and considering the transactional costs, the final price of the product in the domestic market (PD) will be obtained; and by adding the prices of imported goods and domestic goods, the price of composite goods (PQ) will be obtained; and finally by adding the sales tax to the price of composite goods (PQ), the final market price will be obtained. Equation 3 shows the value of all the goods sold in the country, including domestic goods and imported goods. Equation 4 shows the value of the domestic goods, including the goods bought in domestic markets and those from foreign markets. Equations 5, 6, and 7 show the price of the production activity (PA), net price (value-added) of every activity (PVA), and customer price index (CPI) respectively (See Appendix A).

\subsection{Factors and Activities Markets}

In the production factors market, it is assumed that every producer is trying to maximize their benefit, and this benefit is the difference between the revenues earned and the expenditures incurred for production factors and intermediate goods. In maximizing the producer's benefit, every production activity utilizes so many production factors that the final income of every production factor will be equal to the sum paid for it. The sums paid for the factors in every production activity may change not only because of the distinctions between the markets, but also due to the mobility and dynamism of production factors. The production structure and process used in this model is shown in Figure 2. The technical relationship between the production factors, shown in the form of producing value added by the production factors mentioned in this model, is represented through Kab Doghulas Function (Equation 8), and the relationship between production activities and intermediate inputs are described using Leontiff Function 
(Equation 10). In addition, the functions of factors' demands as well as the goods produced in each economic sector are shown in Equations 9 and 11.

\subsection{Commodity Market}

For supplying the commodity in the market, three stages have been considered. These three stages are shown in Figure 3. The first stage includes the Aggregate Domestic Output for each commodity, which is the result of all the different activities. This stage was described in the section on activities and factors market. In the second stage, the Aggregate Domestic Output is divided into the export sales and domestic sales, with the assumption that suppliers are maximizing their sales while paying attention to the Imperfect Transferability between the domestic and foreign markets; as a result, Constant Elasticity of Transformation (CET) functions have been used to represent that (Equation 12). To gain an optimum combination of the distribution of produced goods between domestic sales and exports, we have used Equation 13, which shows the first-stage conditions for maximizing the producers' income according to the relative prices and with the assumption of the Constant Elasticity of Transformation (CET) and the fixedness of the amount of domestic product.

In the third stage, this assumption is taken into account that some foreign goods are imported into the country as a result of interaction with foreign markets; therefore, the goods supplied in the domestic market are a combination of domestic sales products and imported products, which are called "composite goods" (Figure 3).

The demand for such a commodity is subject to this assumption that domestic demanders minimize their costs according to imperfect substitutability between imported commodities and domestic sales. This imperfect substitutability is stated through the constant elasticity of transformation as provided in the Equation 15. The Equation 16 represents the optimum combination of imported and domestic commodities by their relative prices. This equation is indicative of the fact that a relative increase in the prices of domestic commodities as compared to those of imported ones results in increasing the ratio of demand for imports to domestic goods. This means that customers' demands form the markets which provide relatively less expensive goods increases.

\subsection{Institutions}

The institutions considered in the model in question include households, the government and the rest of the world. Households earn their incomes for supplying production factors directly (by supplying labor) and indirectly (by supplying capital) and transformational receipts made by such institutions as the government and the rest of the world sector. Households expend their earnings on paying direct taxes, savings, costs and transitional payments to other institutes. Household costs constitute some part of households' disposable income (i.e. their net income after deducting taxes and transitional payments). These costs are determined according to the marginal propensity consumption as well as the ration of each commodity in the household's consumption basket. The equations 18, 19 and 20 are respectively related to the income of production factors, household's income and household's consumption (Appendix A). Like households, the government also has got income, cost and savings. The government's income comprises different types of taxes, tariffs and oil revenues (Equation 22). Taxes include income tax, sales tax, exports tax, and production tax, and tariffs are mostly imports tariffs. The government spends its income on purchasing consumer goods or transferring it as transitional payments to other institutes (Equation 23). The government's saving is defined as the difference between its income and cost. The rest of the world income refers to the value of the goods imported into the country and the rest of the world cost refer to the payments made for exported goods and transactional payments which are made to other institutions such as households and the government and are calculated in the foreign currency. The external savings are defined as the commercial balance with a negative mark (-). The equations 24,25 , and 26 show the rest of the world income, cost and savings respectively.

\subsection{The Dynamism of the Model}

The structure and relations introduced in the previous parts are related to a Static General Equilibrium Model. In view of the fact that, on the one hand, the impact of savings must be seen in the investment and the appearance of its effects in capital accumulation, the production level, and other variables requires temporal cessation, static models can not display their effects in full. Therefore, in order to remove these shortcomings, the said static model has been expanded into a recursive dynamic e model. To make the model more dynamic, such factors as the growth of labor as well as capital accumulation have been added to it.

\subsubsection{The Growth of Labor}

Due to the fact that supply and demand of labor are in equilibrium, in order to make the model dynamic, it has been assumed that the demand for labor in each period equals the demand for labor in the previous period plus the amount of the growth in demands (Equation 31).

2.5.2 Accumulation of Capital 
The amount of capital accumulated at any juncture equals the sum of the capital accumulated during the previous period plus the net sum of investments made during the current period.

\subsection{Data and Determining the Model Parameters}

The informational basis of General Equilibrium Models has often been the social accounting matrix. Likewise, in the present research a social accounting matrix with necessary dimensions for 2004 has been drawn up by using the input-output tables of the said year as well as the statistics and information released by the Central Bank of Iran. The amounts of the quotients and of the model were estimated and calibrated based on the model data. It is noteworthy that some of the amounts have been extracted from other studies exogenously.

\subsection{Scenarios}

In this study, it is assumed that households save a fixed ratio of their disposable income. This fixed ratio is stated as the marginal propensity to save. In fact, household savings function is a long-term function expressed as the product of marginal propensity to save multiplied by the household disposable income. Therefore, household savings change as a result of any change in the household's marginal propensity to save and/or its disposable income. In this study, the marginal propensity to save has been considered as a policy variable for which two scenarios have been defined:

- The first scenario: 20-percent increase in the household's marginal propensity to save

- The second scenario: 20-percent decrease in the household's marginal propensity to save

\section{Expected Results in the Form of General Equilibrium}

\subsection{Expected Results in the Form of Static General Equilibrium Model}

With the increase in the household's marginal propensity to save, the household's savings, as expressed in the Equation 30, will increase. On the other hand, as the household's marginal propensity to save increases, the amount of the commodities used by that household will decrease (Equation 20). Household's savings are transferred to the financial markets along with the savings of other institutions to be used in the process of investing; as a result, the demand for investing increases as well (Equation 30). The result of demand for investing, the government's marginal demand, and households' consumptions shows the final demand for goods and services (Equation 28).

Since the final demand for composite commodity is a combination of demands for imported goods and domestic sales (Equation 15), any change in demand for composite goods will result in demands for imported goods and domestic sales. According to Equation 12, the commodities produced inside the country with the Constant Elasticity of Transformation functions are divided between domestic sales and exports; therefore, it is expected that the rate of demand for domestic commodities also changes. As the demand for domestic goods changes, the demand for goods produced as a result of production activities also changes (Equation 11). Changes in the demands of production factors, in turn, result in a change in households' incomes (Equation 18 and 19). Such a change in the households' incomes influences both the households' levels of consumption and their savings. The said changes will continue until equilibrium results are acquired in the model.

The government's income comprises different types of taxes, tariffs, and a ratio of the income of the factors; therefore, any change in the government's income is in fact the result of changes in the revenues of production activities, sales income, the value of exports, the value of imports, and the income of production factors (Equation 22). Assuming that the government makes no transitional payments to other institutions, any change in the government's expenditures is subject to changing the consumption expenditures of the government (Equation 23). With respect to the rest of the world accounts, it must be mentioned that any change in the rest of the world income is dependent on changes in the rest of the world expenditures as well as the value of imports in the foreign currency (Equations 24 and 25). The process of effects resulting from the decrease in the marginal propensity to save on the economic variables is similar to the process resulting from its increase; however, the direction of changes will be opposite to that of the changes resulting form the increase in household's marginal propensity to save.

\subsection{Expected Results in the Form of Dynamic General Equilibrium}

With the increase in the household's marginal propensity to save, it is expected that households' savings, which are a direct function of the marginal propensity to save, increase to a higher level in the basic scenario (Equation 30). Due to savings-investment equality, any rise in the household's savings will lead to a rise in the demand for investing; hence, it is expected that investment in the first scenario and throughout all the years being considered ranks a higher level than investment in the basic scenario. With the increase in the demand for investing, the demand for composite commodities (Equation 28) increases, and in view of the fact that composite commodities are considered a function of imported goods and domestic sales (Equation 15 and 17), any increase in the demand for composite commodities will result in a rise in demand for imported goods and domestic sales, each of which needs 
to rank a higher level than their sum in the basic scenario. According to Equations 12 and 14, domestic goods will also increase as a result of a rise in the demand for domestic sales, which in turn will result in an increase in the demand for manufactured goods (Equation 11). The rise in the demand for manufactured goods will result in an increase in the demand for intermediate goods (Equation 10) and an increase in the demand for manufacturing factors (Equations 8 and 9). According to Equations 18 and 19, households earn their income from supplying manufacturing factors; and with the rise in the demand for manufacturing factors, households' incomes will increase accordingly. It is noteworthy that transitional payments from other institutions to households have been considered zero. Due to the increase in households' incomes, it is expected that their consumption will also increase (Equation 20). The mechanism of changing the variables as a result of the decrease in household marginal propensity to save (second scenario) is exactly the same as the mechanism of the increase in household marginal propensity to save. The only difference is that the direction of changes in the second scenario will be opposite to that in the first scenario.

\section{An Analysis of General Equilibrium Model Results}

\subsection{An Analysis of Static General Equilibrium Model Results}

A 20-percent increase in households' marginal propensity to save has helped their savings to increase by around 20 percent. Such an increase in household's savings has resulted in a 3.8-percent decrease household's consumption in all economic sections. According to the saving-investing account, the total sum of a community's savings equals the sum of its investment. Any change in demand for investing will result in changes in demand for various commodities as well as production factors, which in turn will influence households' incomes. The analysis of the changes in households' incomes are indicative of the fact that the income earned by urban and rural households from supplying labor and capital as a result of the first scenario has increased by 0.5 and 0.31 percent respectively (Table 2).

In Table 3, the amount of changes in gross domestic product (GDP) and its elements for the sections under study have been shown. As you can see, households' consumption expenditures have decreased in all sections by 3.86 percent, which is quite compatible with the assumption that households' incomes are spent on saving and consumption. The government's expenditures show a very slight change; however, investment expenditure manifest the most remarkable change amongst the elements of gross domestic product (GDP), whose average increase in all sections amounts to 9.92 percent. The highest increase can be seen in gas and oil section. The net exports in agriculture section as well as mining and industry section have decreased by 3.59 percent and 1.89 percent respectively, while it has increased in oil and gas sections by 0.5 percent and 0.61 percent respectively. This indicates that as household savings increase, the imports of such sections as agriculture and mining and industry will exceed their exports. The gross national product (GNP) has also increased in all sections. the highest increase, which amounts to 12.2 percent, belongs to the Oil \& gas section.It must be noted that the results of implementing the second scenario, i.e. the decrease in household marginal propensity to save by $20 \%$, were exactly opposite to those of implementing the first scenario.

\subsection{An Analysis of Dynamic General Equilibrium Model Results}

Following the implementation of the first scenario, households' incomes increase to a level higher than households' incomes in the basic scenario. With the implementation of the second scenario, households' savings throughout all the years under study decrease to a level lower than households' savings in the basic scenario (Figure 4)

The average amount of household savings in the first scenario during the 30 years under study adds up to 598259 billion IR Rials, which shows a 27.7-percent increase as compared with its average amount in the basic scenario. The average amount of household savings in the second scenario during the 30 years under study adds up to 350671 billion IR Rials, which shows a 25.15-percent decrease as compared with its average amount in the basic scenario. In addition, total savings - comprising household savings, the government's saving and rest of the world savings whose average amounts to 753812 billion IR Rials in the first scenario, has increased by 16.33 percent as compared with the basic scenario. The implementation of the second scenario leads to decreasing the average of total savings to 550772 billion IR Rials, that is to say a 15-percent decrease in comparison with the basic scenario (Table 4).

Table 5 shows the average household income in urban and rural households. As it is quite obvious, the average incomes of urban and rural households have respectively increased to 2255773 and 1002755 billion IR Rials as a result of implementing the first scenario; however, they have respectively decreased to 1983309 and 881652 by implementing the second scenario. Through implementing the first scenario, i.e. a 20-percent increase in household savings, the total household income increases by 6.42 percent, while it decreases by the same rate as a result of implementing the second scenario. This corroborates a positive relationship between household savings and urban and rural households' income. The time trend of households' total income has been illustrated in Figure 5. 
By implementing the first scenario, the gross national product (GDP) increases to a level higher than the GDP in the basic scenario. On the contrary, by implementing the second scenario, the GDP decreases to a level lower than the GDP in the basic scenario (Figure 6). The amount and percentage of increase in the GDP resulting from the implementation of the first and second scenarios in different sectors have been provided in Table 6 . The average GDP resulting from the implementation of the first scenario amounts to 3991683 billion IR Rials, which shows a 9.66-percent increase as compared with the basic scenario. The highest increase amongst various sectors belongs to the building sector, whose average GDP is 16.27 percent higher than its average GDP in the basic scenario. As a result of implementing the second scenario, the average GDP decreases by 9.56 percent. It is quite obvious that the result of the second scenario is the symmetry of that of the first.

\section{Summary and Conclusion}

Achieving higher production and economic growth requires new investments. The amount of investment in any country depends on the amount of savings in that country. In view of the fact that household savings comprise a large part of a country's savings, we tried in this paper to investigate the impact of household savings on household income as well as gross domestic product (GDP). In line with this, two General Equilibrium Models, i.e. Static Computable General Equilibrium (CGE) Models and Dynamic Computable General Equilibrium Models, have been used. Since the household savings function has been considered a long-term Kinsey savings function, the change of households' marginal propensity to save has been used. In the Static Model, the analysis of the changes in household income indicates that the income earned by urban and rural households from supplying labor and capital as a result of the implementation of the first scenario has increased by 0.5 and 0.31 percent respectively. The gross domestic product (GDP) has also increased in all sectors. The highest amounts of increase are related to Oil \& gas and building sectors and amount to 12.2 and 9.07 percent respectively.

In the dynamic model, when household savings increase by 20 percent as a result of implementing the first scenario, both urban and rural households' income increase by 6.42 percent. However, when the second scenario is implemented, it decreases by the same rate. This shows a direct relationship between household savings and urban and rural households' income. When the first scenario is implemented, the average GDP amounts to 39991683 IR Rials, which represents a 9.66-percent increase as compared with the basic scenario. The highest increase amongst various sectors is related to the building sector, which has been 16.27 percent higher than that of the basic scenario. When the second scenario is implemented, the average GDP decreases by 9.56 percent as compared with the basic scenario.

\section{References}

Aghevli, B.B, Boughton, J. M, Motiol, P.J, Villanueva, D, \& Woglom, G. (1990). The Role of National Saving in the World Economy, Recent Trends and Prospects, IMF, Occasional Paper, No 67

Ansari, Mohammed. (2004). Sustainability of the US Current Account Deficit: An Economic Analysis of the Impact of Capital Inflow on Domestic Economy. Journal of Applied Economics. Vol. 11, No. 2, PP.249-296

Armington, P.S. (1969). A Theory of Demand for Products Distinguished by Place of Production, International Monetary Fund Staff Papers, Vol. 16, pp. 159-76. http://dx.doi.org/10.2307/3866403

Baharum Shah, Ahmad. Zubaidi, \& Marwan, Abdul-Malik. (2006). Foreign Copital Flow and Economic Growth in East Asian Countries. China Economic Review. Vol. 17, pp.70-83. http://dx.doi.org/10.1016/j.chieco.2005.09.001

Cardenas, M., \& Escobar, A. (1998). Saving Determinants in Colombia: 1925-1994. Journal of Development Economics, Vol 57, 1998, pp5-44

Computable General Equilibrium Models. Online available at www.unescap.org/drpad/vc/orientation/..htm

Craigwell, Ronald, \& Lewyn, Rock. (1992). Dynamic Saving Behavior in an Oil Dependent Economy, the Case Of Trinidad \& Tobago. Journal of Development Economics, No. 39, pp.247-261, http://dx.doi.org/10.1016/0304-3878(92)90039-C

Dayal-gulalti, A., \& Thimann, C. (1997). Saving in South East Asia and Latin America, IMF, working paper, No 97, pp.7-12

Dervis, k.j., De Melo, \& Robinson. (1982). General Equilibrium Model for Development Policy, Cambridg University Press

Kwack, Sung Yeung, \& Young Sun, Lee. (2005). What Determines Saring Rotes in Korea? The Role of Demography. Journal of Asian Economics, Vol. 16, pp. 861-873, http://dx.doi.org/10.1016/j.asieco.2005.08.014

Lofgren, Hans. (2001). External Shockes and Domestic Poverity, Alleviation, International Food Policy Research Institute, Washengton, 
Lofgren, Hans. (2001). A CGE Model for Malawi, International Food Policy Research Institute, Washengton, No.70 Lofgren,H., Harris, R.B., \& Robinson, S. (2002). A Standard Computable General Equilibrium(CGE) Model in $G A M S$, International Food Policy Research Institute.

Lofgren, Hans. (2003). Exercise in General Equilibrium Modeling Using GAMS, International Food Policy Research Institute, Washengton,

Looney.E. R. (2001). National Savings and Economic Growth in Pakistan, Naval Postgraduate School, Available From: http://web.navy.miL/

Maccarl,s Gams user Guide. (2003). Online at www.gams.com/docs/contributed/index.htm

Mari, M.T.A, A.M.C, \& Ramos, V.O, Rios. (2003). Net Foreign Resource Inflows, Savin and Growth: Spain (1970-1999), European Trade Study Group, Fifth Annual Conference- Madrid, International European Trade Study Group. ISBN

McCarl, B.A., \& Gillig, D. (2002). Note on Formulation and Solving Computable General Equilibrium Model Within GAMS, Department of Agricultural Economics College Station, TX, pp. 845-1706

Mohan, Ramesh. (2006). Causal Relationship Between Savings And Economic Growth In Countries With Different Income Levels. Economics Bulletin, Vol. 5, No. 3, pp 1-12

Mohey-Ud- di, Ghulam. (2006). Impact of Foreign Capital Inflows (FCI) on GDP Growth in Pakistan (1975-2004) Munich Personal ReREC Archive, MPRA Paper, No. 1133, pp. 1-13

Pyatt, G. (1988). A SAM Approach to Modeling, Journal of Policy Modeling, 10(3): 327-52. http://dx.doi.org/10.1016/0161-8938(88)90026-9

Roberto Roson. (2005). Introducing Imperfect Competition in CGE Model, online at www.disefin.onige.it/finanza/...htm

Sue Wing, 1. (2004). Computable General Equilibrium Models and Their Use in Economy-Wide Policy Analysis, Boston University, pp.1-48

Thurlow, J. (2004). A Dynamic Computable General Equilibrium (CGE) Model for South Africa, Trade and Industrial Policy Strategies (TIPS), pp.1-99.

Vito Tanzi, \& Howell H. Zee. (1998). Taxation and the Household Saving Rate, Evidence from OECD Countries, IMF working paper, pp5-10

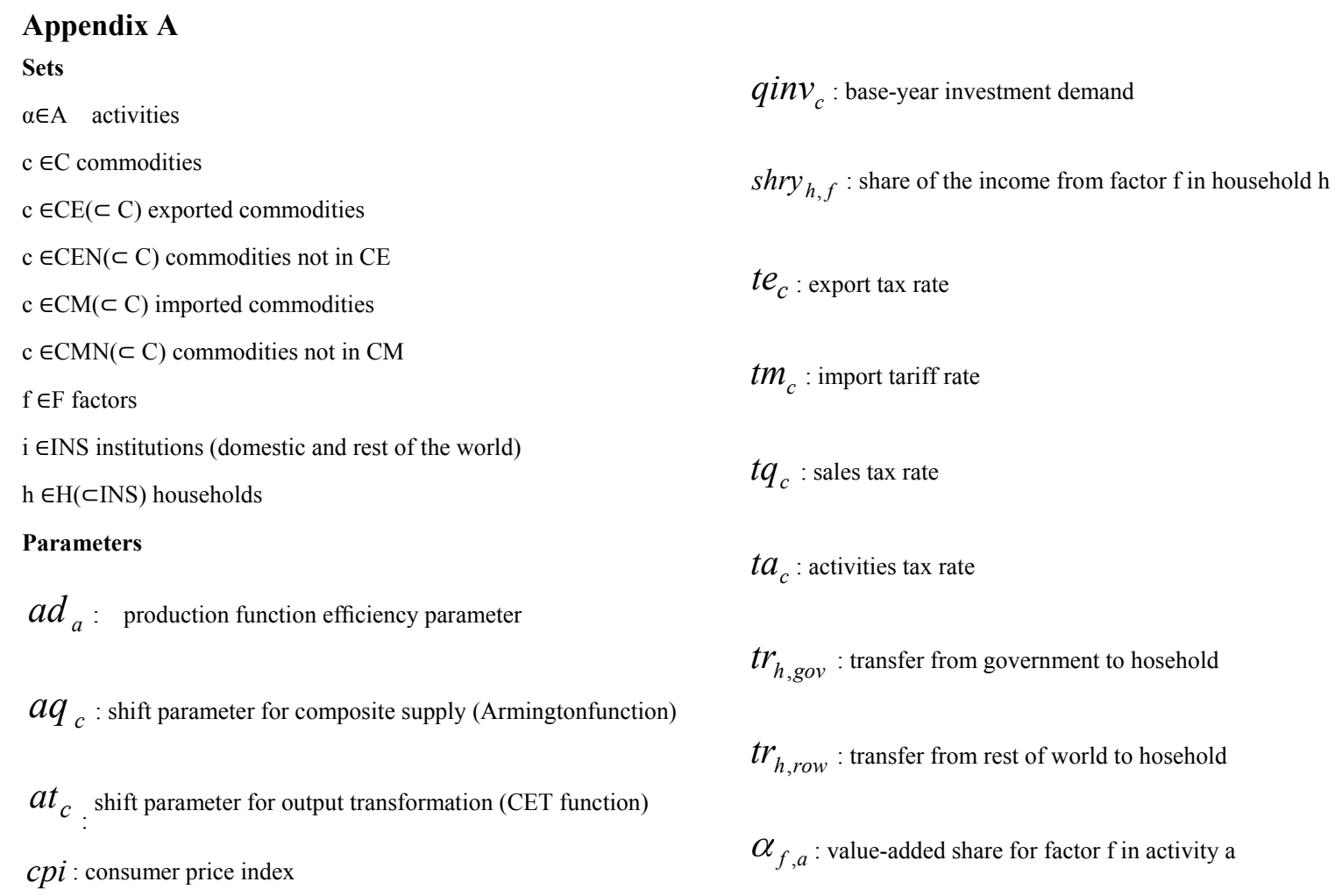


cwts ${ }_{c}$ : commodity weight in CPI

$i c a_{c a}$ : quantity of $\mathrm{c}$ as intermediate input per unit of activity a

$m p s_{h}$ : share of disposable household income to savings

$p w e_{c}$ : export price (foreign currency)

$p w m_{c}:$ import price (foreign currency)

$q g_{c}:$ government commodity demand

$\varphi_{f}:$ Capital sectoral mobility factor

$\operatorname{shrg}_{f}$ : share of government in factors income

Variables:

$E G$ : government expenditure

$E X R$ : foreign exchange rate (domestic currency per unit of foreign currency)

$F S A V$ : foreign savings

$Y R O W$ : Income of rest of world

EROW : expenditure of the rest of world

$I A D J$ : investment adjustment factor

$P A_{a}:$ activity price

$P V A_{a}$ : value-added price

$P D_{c}$ : domestic price of domestic output

$P E_{c}$ : export price (domestic currency)

$P M_{c}$ : import price (domestic currency)

$P Q_{c}$ : composite commodity price

$P X_{c}$ : producer price

$Q A_{a}:$ activity level

$Q D_{c}$ : quantity of domestic output sold domestically

$Q E_{c}$ : quantity of exports

$\beta_{c, h}$ : share of commodity $\mathrm{c}$ in the consumption of household $\mathrm{h}$ $\delta_{c}^{q}$ : share parameter for composite supply (Armington) function

$\delta_{c}^{t}$ : share parameter for output transformation (CET) function

$\theta_{a, c}$ : yield of commodity c per unit of activity a

$\rho_{c}^{q}$ : exponent for composite supply (Armington) function

$\rho_{c}^{t}$ : exponent for output transformation (CET) function

remp : employment rate

$t y_{h}:$ hosehold income tax rate

$\eta_{f, a, t}:$ Sector share of new capital

$Q F_{f, a}:$ quantity demanded of factor $\mathrm{f}$ by activity a

$Q H_{c, h}:$ quantity of consumption of commodity c by household $\mathrm{h}$

$Q I N T_{c}$ : quantity of intermediate use of commodity c by activity a

$Q D I N V_{c}$ : quantity of investment demand

$Q M_{c}$ : quantity of imports

$Q Q_{c}$ : quantity supplied to domestic commodity demanders (composite supply)

$Q X_{c}$ : quantity of domestic output

$W F_{f}$ : average wage (rental rate) of factor $\mathrm{f}$

wfdist $_{f, a}$ : wage distortion factor for factor $\mathrm{f}$ in activity a

$Y F_{h, f}$ : transfer of income to household $\mathrm{h}$ from factor $\mathrm{f}$

$Y G$; government revenue

$\mathrm{YH}_{h}$ : household income

$D K_{k, a, t}$ : Quantity of new capital by activity a for time period $\mathrm{t}$

$P K_{f, t}$ : Unit price of capital in time period $\mathrm{t}$ 


\section{Equations}

1. $P M_{c}=\left(1+t m_{c}\right) \times P W M_{c} \times E X R$

2. $P E_{i}=\left(1-t e_{c}\right) \times P W E_{c} \times E X R$

3. $P X_{c} \times Q X_{c}=P D_{c} \times Q D_{c}+P E_{c} \times Q E_{c}$

4. $P Q_{c} \times Q Q_{c}=\left(1+t q_{c}\right) \times\left[P D_{c} \times Q D_{c}+P M_{c} \times Q M_{c}\right]$

5. $P A_{a}=\sum_{c} \theta_{a, c} \times P X_{c}$

6. $P V A_{a}=P A_{a}-\sum_{c} P Q_{c} \times i c a_{c a}$

7. $c p i=\sum_{c} P Q_{c} \times c w t s_{c}$

8. $Q A_{a}=a d_{a} \times \prod_{f} Q F_{f, a}^{\alpha_{f}}$

9. $Q F_{f, a} \times w f d i s t_{f, a} \times W F_{f}=\alpha_{f, a} \times P A_{a} \times Q A_{a}$

10. $Q I N T_{c a}=i c a_{c a} \times Q A_{a}$

11. $Q X_{C}=\sum_{a} \theta_{a c} \times Q A_{a}$

12. $Q X_{c}=a t_{c}\left(\delta_{c}^{t} \times Q E_{c}^{\rho^{\prime} c}+\left(1-\delta_{c}^{t}\right) \times Q D_{c}^{\rho_{c}^{t}}\right)^{1 / \rho_{c}^{t}}$

13. $Q E_{c} / Q D_{c}=\left(P E_{c} / P D_{c} \times \frac{1-\delta_{c}^{t}}{\delta_{c}^{t}}\right)^{\frac{1}{\delta_{c}^{c}-1}}$

14. $Q X_{c}=Q D_{c}$

15. $Q Q_{c}=a q_{c}\left(\delta_{c}^{q} \times Q M_{c}^{-\rho_{c}^{q}}+\left(1-\delta_{c}^{q}\right) \times Q D_{c}^{-\rho_{c}^{q}}\right)^{-1 / p_{c}^{q} a}$

16. $Q M_{c} / Q D_{c}=\left(P D_{c} / P M_{c}\right) \times\left(\frac{\delta_{c}^{q}}{1-\delta_{c}^{a}}\right)^{1 / 1+\rho_{c}^{q}}$

17. $Q Q_{c}=Q D_{c}$

18. $Y F_{f}=\operatorname{shry}_{h f} \sum_{a} w f d i s t_{f, a} \times W F_{f} \times Q F_{f, a}$

19. $Y H_{h}=\sum_{f} Y F_{h f}+t r_{h, g o v}+E X R \times t r_{h, \text { row }}$

20. $Q H_{c, h}=\frac{\beta_{c h} \times\left(1-m p s_{h}\right) \times\left(1-t y_{h}\right) \times Y H_{h}}{P Q_{c}}$

21. $Q D I N V_{c}=q i n v_{c} \times I A D J$
$Y G=\sum_{h} t y_{h} \times Y H_{h}+E X R \times t r_{\text {gov, row }}+\sum_{c} t q_{c} \times$

22. $\begin{aligned} & {\left[P D_{c} \times Q D_{c}+P M_{c} \times Q M_{c}\right]+} \\ & \sum_{c}\left(t m_{c} \times E X R \times p w m_{c} \times Q M_{c}\right)+\sum_{c} t e_{c} \times E X R \times p w e_{c} \times Q E_{c}\end{aligned}$ $\sum_{a}^{c} t a_{c} \times P A_{a} \times Q A_{a}+\sum_{f} s h r g_{f} \times \sum_{a}^{c}\left(w_{f d i s t_{f, a}} \times W F_{f} \times Q F_{f, A}\right)$

23. $E G=\sum_{h} t r_{h, g o v}+\sum_{c} P Q_{c} \times q g_{c}$

24. $Y R O W=\sum_{c} p w m_{c} \times Q M_{c}$

25. $E R O W=\sum_{c} p w e_{c} \times Q E_{c}+\sum_{i} t r_{i, r o w}$

26. $F S A V=Y R O W-E R O W$

27. $Q F S_{f}=\sum_{a} Q F D_{f, a}$

28. $Q Q_{c}=\sum_{a} Q I N T_{c a}+\sum_{h} Q H_{c h}+q g_{c}+Q D I N V$

29. $\sum_{c} p w m_{c} \times Q M_{c}=\sum_{c} p w e_{c} \times Q E_{c}+\sum_{i} t r_{i, r o w}+F S A V$

30. $\begin{aligned} & \sum_{h}^{h} m p s_{H} \times(1-t y) \times Y H_{b}+(Y G-E G)+ \\ & E X R \times F S A V=\sum P Q_{c} \times Q D I N V_{c}\end{aligned}$

31. $Q F_{l, a, t}=Q F_{l, a, t-1} \times(1+$ remp $)$

32. $a w f_{f, t}=\sum_{a}\left[\left(Q F_{f, a, t} / \sum_{a^{\prime}} Q F_{f, a^{\prime}, t}\right) \times W F_{f, t} \times w f d i s t_{f, a, t}\right]$

33. $\eta_{f, a t}=\left(Q F D_{, a t} / \sum_{d} Q F D_{, d t}\right) \times \varphi_{f}\left[\left(\left[F_{f+} \times w f d i s f_{, a t} / a w f_{f \neq}\right)-1\right]+1\right]$

34. $D K_{f, a, t}=\eta_{f, a, t} \times\left[\sum_{i} P Q_{i, t} \times Q D I N V_{i, t} / P K_{f, t}\right]$

35. $P K_{f, t}=\sum_{i} P Q_{i, t} \times\left[Q D I N V_{i, t} / \sum_{i} Q D I N V_{i, t}\right]$

36. $Q F_{k, a, t}=Q F D_{k, a, t-1} \times\left[1+\left(D K_{k, a, t-1} / Q F D_{k, a, t-1}\right)-d e p_{k}\right]$ 
Table 1. Model Categories and their Subcategories

\begin{tabular}{|l|l|}
\hline \multicolumn{1}{|c|}{ Categories } & \multicolumn{1}{c|}{ Subcategories } \\
\hline Activities & Agriculture, Mining \& Industry, Oil \& Gas, Services, Building \\
\hline Goods & Agriculture, Mining \& Industry, Oil \& Gas, Services, Building \\
\hline Production Factors & Labor Force, Capital \\
\hline Households & Urban and Rural Households \\
\hline Investment-Saving & Agriculture, Mining \& Industry, Oil \& Gas, Services, Building \\
\hline Other Institutions & Government, Rest of World \\
\hline
\end{tabular}

Source: research findings

Table 2. The Percentage of Changes in Households' Income as a Result of a 20-percent Increase in the Marginal Propensity to Save

\begin{tabular}{|l|c|c|c|}
\hline & Households & Production Factors & Percentage of Changes \\
\hline \multirow{3}{*}{ Households' Income from Production Factors } & \multirow{2}{*}{ Urban } & Labor & 0.05 \\
\cline { 3 - 4 } & & Capital & 0.31 \\
\cline { 3 - 4 } & \multirow{2}{*}{ Rural } & Labor & 0.05 \\
\cline { 3 - 4 } & & Capital & 0.31 \\
\hline
\end{tabular}

Source: research findings

Table 3. The Percentage of Changes in GDP and its Elements as a result of a 20-percent Increase in the Marginal Propensity to Save

\begin{tabular}{|c|c|c|c|c|c|}
\hline & \multicolumn{5}{|c|}{ Commodities } \\
\cline { 2 - 6 } & Agriculture & Oil \& gas & Mining \& industry & Building & Services \\
\hline Consumption Expenditure & -3.86 & ----- & -3.86 & -3.86 & -3.86 \\
\hline Government's Expenditures & 0.10 & ----- & -0.02 & ----- & -0.03 \\
\hline Investment Expenditures & 9.14 & 12.63 & 9.00 & 9.84 & 9.00 \\
\hline Net Exports & -3.59 & 0.5 & -1.89 & ----- & 0.61 \\
\hline Gross Domestic Product (GDP) & 4.67 & 12.20 & 3.80 & 9.07 & 2.55 \\
\hline
\end{tabular}

Source: research findings

Table 4. Institutions' Savings Resulting from the Implementation of the Different Scenarios

\begin{tabular}{|c|c|c|c|c|c|}
\hline \multirow{2}{*}{} & Basic Scenario & \multicolumn{2}{|c|}{ First Scenario } & \multicolumn{2}{c|}{ Second Scenario } \\
\cline { 2 - 6 } & Average & Average & Changes (\%) & Average & Changes (\%) \\
\hline Households' Savings & 468493 & 598259 & 27.70 & 350671 & -25.15 \\
\hline Government's Savings & 542041 & 577725 & 6.58 & 506331 & -6.59 \\
\hline Rest of the world Savings & -362557 & -422172 & 16.44 & -306231 & -15.54 \\
\hline Total savings & 647976 & 753812 & 16.33 & 550772 & -15 \\
\hline
\end{tabular}

Source: research findings

Table 5. Household Income Resulting from the Implementation of the Different Scenarios

\begin{tabular}{|c|c|c|c|c|c|}
\hline & Basic Scenario & \multicolumn{2}{|c|}{ First Scenario } & \multicolumn{2}{c|}{ Second Scenario } \\
\cline { 2 - 6 } & Average & Average & Changes (\%) & Average & Changes (\%) \\
\hline Urban Household & 2119741 & 22557333 & 6.42 & 1983309 & -6.44 \\
\hline Rural Household & 942301.5 & 1002755 & 6.42 & 881652 & -6.42 \\
\hline Total Income & 3062042 & 3258489 & 6.42 & 881652 & -6.43 \\
\hline
\end{tabular}

Source: research findings 
Table 6. GDP Resulting from the Implementation of Different Scenarios

\begin{tabular}{|c|c|c|c|c|c|}
\hline \multirow{2}{*}{} & Basic Scenario & \multicolumn{2}{|c|}{ First Scenario } & \multicolumn{2}{c|}{ Second Scenario } \\
\cline { 2 - 6 } & Average & Average & Changes (\%) & Average & Changes (\%) \\
\hline Agriculture & 428326.9 & 434221.7 & 7.38 & 419728.6 & -8.01 \\
\hline Oil \& Gas & 1169425 & 1266691 & 8.32 & 1074015 & -8.16 \\
\hline Mining and Industry & 535306.3 & 546294.7 & 8.05 & 521310.7 & -8.61 \\
\hline Building & 96914.3 & 112687 & 16.27 & 82385.7 & -14.99 \\
\hline Services & 1715170 & 1857162 & 8.28 & 1577504 & -8.03 \\
\hline Total & 3751315 & 3991683 & 9.66 & 3510173 & -9.56 \\
\hline
\end{tabular}

Source: research findings

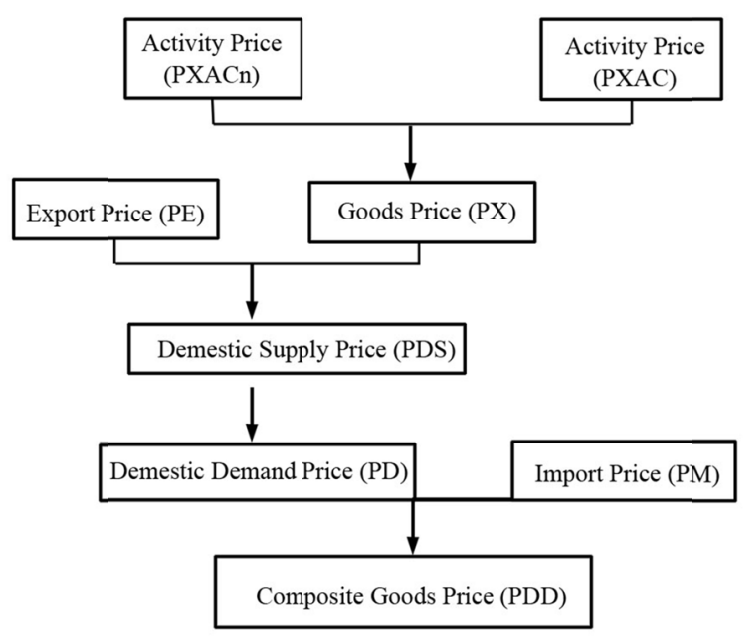

Figure 1. The Relations between Prices

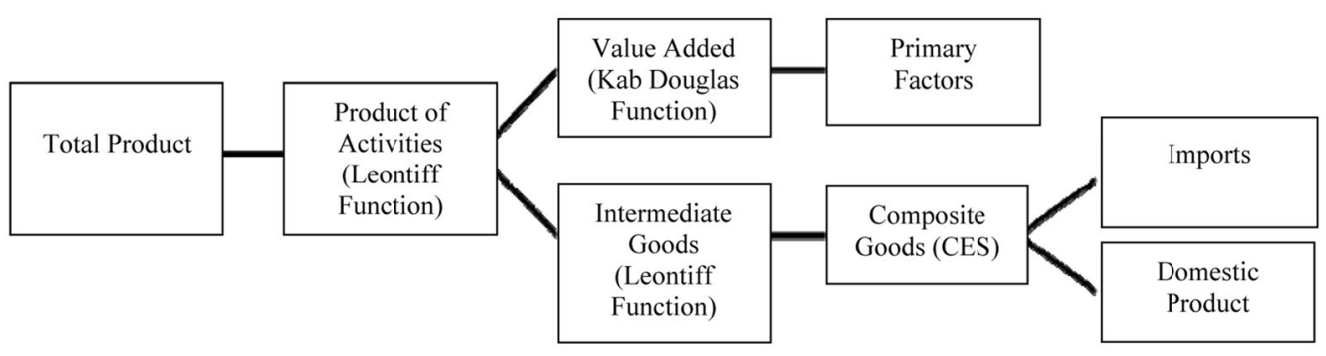

Figure 2. The Production Structure in the General Equilibrium Model

Source: lofgren and et al, 2002 


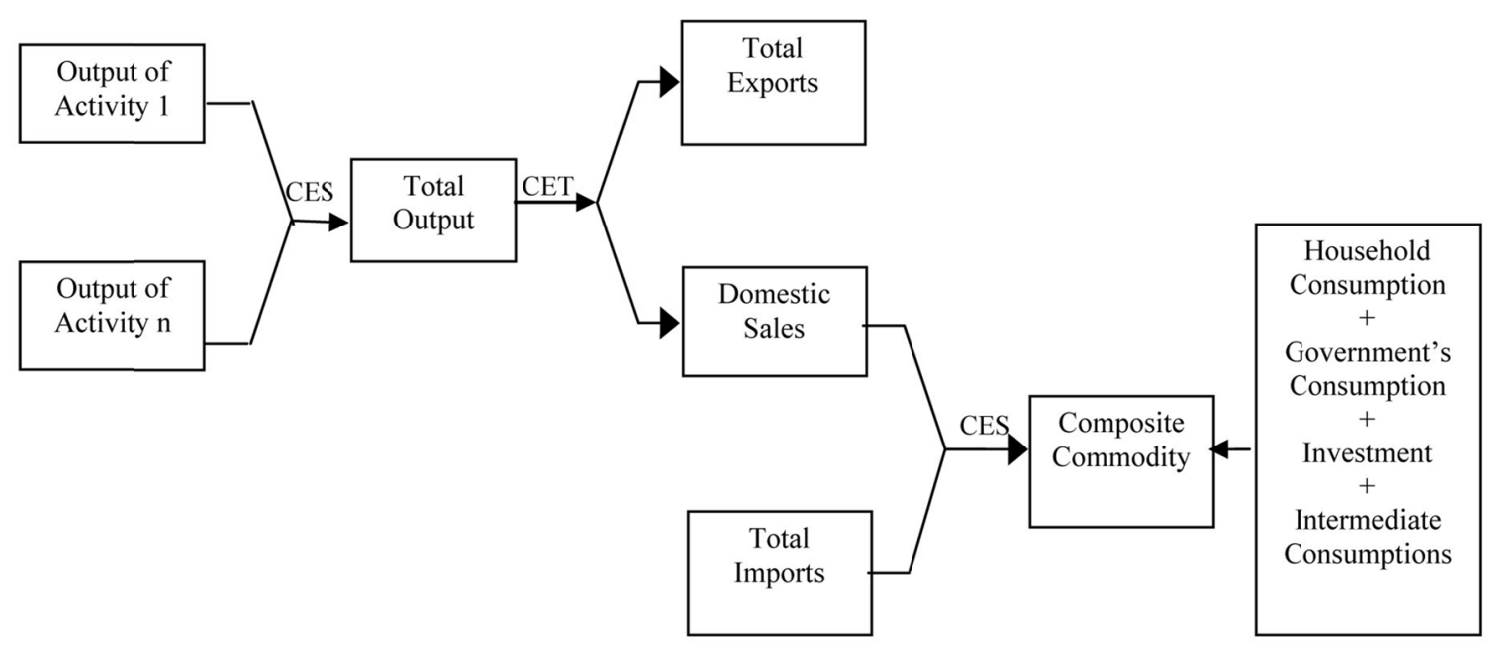

Source: lofgren and et al, 2002

Figure 3. The Flow of Goods in General Equilibrium Models

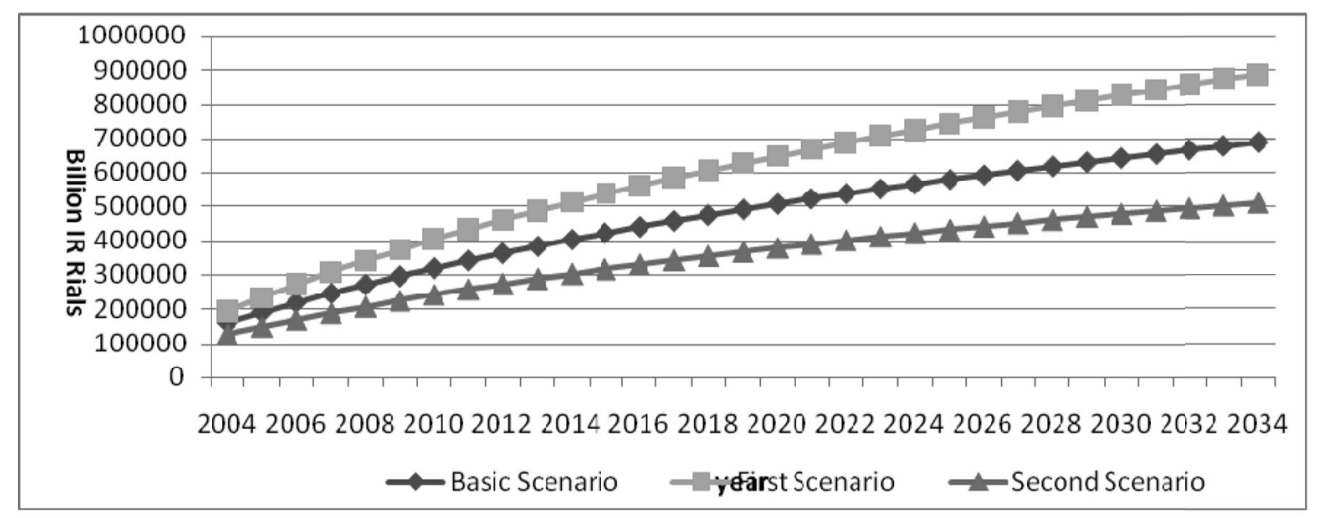

Figure 4. The Trend of Household Savings Resulting from the Implementation of Different Scenarios

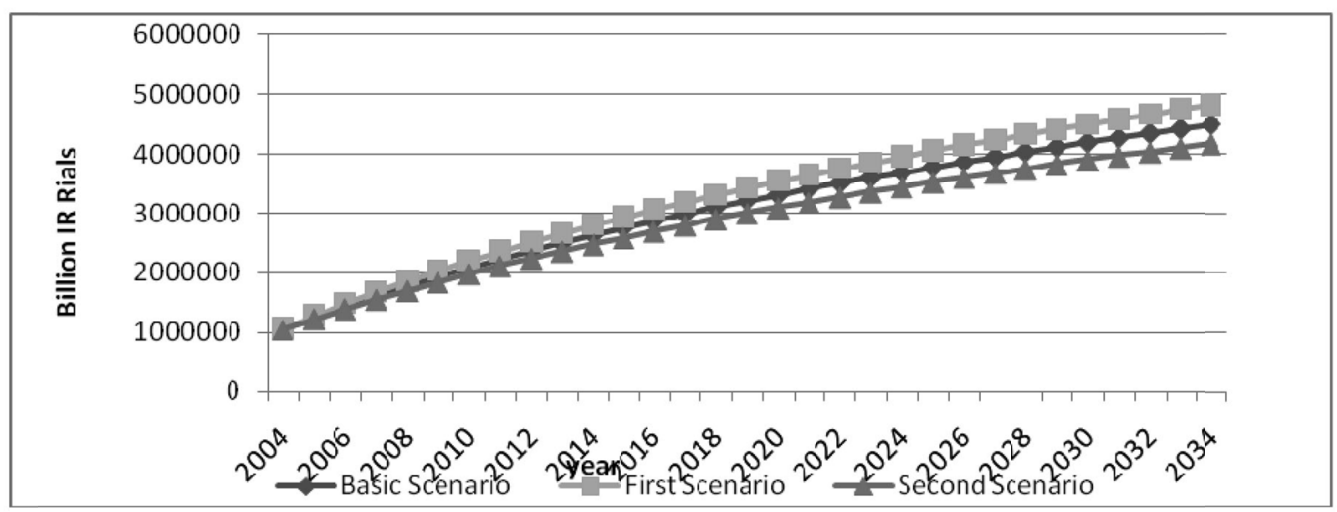

Figure 5. The Trend of Households' Income Resulting from the Implementation of Different Scenarios 